\title{
Quantification of Mineral Composition and Total Protein Content in Sorghum [Sorghum Bicolor (L.) Moench] Genotypes
}

\author{
A.S. Gerrano ${ }^{1,2 *}$, M.T. Labuschagne ${ }^{1}$, A. van Biljon ${ }^{1}$ and N.G. ShargiE $^{3}$ \\ ${ }^{1}$ Department of Plant Sciences, University of the Free State, P.O. Box 339, Bloemfontein 9300, South Africa \\ ${ }^{2}$ Agricultural Research Council - Vegetable and Ornamental Plants Institute, Private Bag X293, \\ Pretoria 0001, South Africa \\ ${ }^{3}$ Agricultural Research Council - Grain Crops Institute, Private Bag X1251, Potchefstroom 2520, \\ South Africa \\ (Received 8 May 2015; Accepted 13 July 2015; \\ Communicated by F. Békés)
}

\begin{abstract}
Sorghum is a drought tolerant cereal and staple food which is a dietary source of protein and more than 20 minerals. The concentration of the mineral elements and protein content in sorghum varies due to genotypic and environmental influences and genotype by environment interactions. The objective of this study was to determine the contents of eight mineral elements $(\mathrm{Ca}, \mathrm{Fe}, \mathrm{K}, \mathrm{Mn}, \mathrm{Na}, \mathrm{P}, \mathrm{Zn}$ and $\mathrm{Mg}$ ) and protein in sorghum genotypes. The analysis of variance showed significant differences in mineral and protein contents. There was a significant relationship between $\mathrm{Zn}$ and $\mathrm{Fe}$ and between protein and $\mathrm{P}$ and $\mathrm{Zn}$. The principal component (PC) analysis showed that $\mathrm{Fe}, \mathrm{Mn}, \mathrm{P}, \mathrm{Zn}$ and protein contributed largely to clustering of the genotypes in $\mathrm{PC} 1 ; \mathrm{Ca}, \mathrm{P}$ and $\mathrm{Mg}$ to $\mathrm{PC} 2$ and $\mathrm{Ca}, \mathrm{K}$ and $\mathrm{Na}$ to $\mathrm{PC} 3$. The presence of a considerable amount of compositional variability of mineral and protein contents among tested genotypes suggests that they can be a valuable source of genes for nutritional quality improvement of sorghum.
\end{abstract}

Keywords: mineral content, principal component analysis, protein, sorghum

\section{Introduction}

In Africa, grain sorghum ranks second among cereals for human consumption. Sorghum has an advantage of being drought tolerant and many subsistence farmers in these regions cultivate it as a staple food crop for consumption (Murty and Kumar 1995). Sorghum contains protein (6-25\%), ash (1.2-1.8\%), oil (3.4-3.5\%), fiber (2.3-2.7\%) and carbohydrate (71.4-80.7\%) with dry matter ranging from 89.2 to $95.3 \%$ depending on the type of cultivar (Lasztity 1996; Samia et al. 2005; Idris et al. 2007). Further, they reported that sorghum flour contained 11.0-13.0, 285-310 and 4.0-5.50 mg $100 \mathrm{~g}^{-1} \mathrm{Ca}, \mathrm{P}$ and Fe, respectively. Sorghum is reported to be a good source of more than 20 minerals (BSTIDNRC 1996; Dicko et al. 2006) and is also rich in P, K, Fe, and Zn (Glew et al. 1997; Anglani 1998; Dicko et al. 2006).

\footnotetext{
*Corresponding author; E-mail: agerrano@arc.agric.za
} 
Furthermore, it is a staple crop for people living in water-stressed regions in Ethiopia and acts as a source of energy, protein, vitamins and minerals (Klopfenstein and Hoseney 1995). Breeding of cereal crops with increased protein and micronutrient concentration requires genetic variation in the trait among germplasm (Morgounov et al. 2007). Selection and development of new varieties for a higher concentration of mineral elements through evaluation will help to improve human health (Gorz et al. 1987). Previous work with several plant species suggested that mineral concentration was under genetic control and that considerable progress was possible by selecting for either high or low mineral accumulation (Gorz et al. 1987).

Intensive plant breeding programmes have increased yields of sorghum grain but little attention has been paid to the nutritional quality of the grain. Therefore, the objective of this study was to study the compositional variation in mineral elements and protein contents of grain of sorghum genotypes and determine association between them.

\section{Materials and Methods}

\section{Plant material}

The experimental material comprised of 22 sorghum cultivars obtained from the Institute of Biodiversity Conservation Gene Bank of Ethiopia (Table 1) and Agricultural Research Council - Grain Crops Institute, South Africa. The study was conducted on the research farm of the Agricultural Research Council - Grain Crops Institute in South Africa located at Potchefstroom (26 $74^{\prime}$ 'S; 27 ${ }^{\circ}$ 'E) during the 2009 and 2010 growing seasons. Potchefstroom is located at an altitude of $1344 \mathrm{~m}$ above sea level and the average minimum and maximum temperature is $9.61{ }^{\circ} \mathrm{C}$ and $25.48^{\circ} \mathrm{C}$, respectively, with an average annual total rainfall of $618.88 \mathrm{~mm}$.

\section{Mineral analyses}

Sorghum kernels were ground into a fine powder with an IKA Analysis A10 Grinder. Two gram flour samples were weighed, placed into porcelain crucibles and the dry ashing procedures were used for determination of $\mathrm{Ca}, \mathrm{Mg}, \mathrm{Mn}, \mathrm{Zn}, \mathrm{Fe}, \mathrm{Na}, \mathrm{K}$ and $\mathrm{P}$ in the Soil Laboratory, Department of Soil, Crop and Climate Sciences at the University of the Free State. Samples were placed in a muffle furnace at $550{ }^{\circ} \mathrm{C}$ for $3 \mathrm{~h}$ after which samples were acid-digested by addition of $1 \mathrm{ml}$ of $55 \%(\mathrm{v} / \mathrm{v}) \mathrm{HNO}_{3}$ after cooling. The acid was evaporated from the samples using a sand bath and oven dried in the muffle furnace again. Ten $\mathrm{ml}$ of $1: 2 \mathrm{v} / \mathrm{v} 55 \% \mathrm{HNO}_{3}$ solution was added to the samples to moisten them and placed in the sand bath for 5-10 min to warm it up. The samples were stirred in porcelain crucibles using glass rods and transferred into $100 \mathrm{ml}$ volumetric flasks. The samples were shaken immediately and allowed to dissolve overnight to extract the minerals. The samples were then transferred into glass test tubes and diluted with distilled water 100 times. Mineral concentrations were then determined by an Atomic Absorption Spectrophotometer (SpectrAA 300). 


\section{Protein content determination}

Flour samples $\left(250 \mathrm{mg}\right.$ ) were weighed, oven dried over night at $95^{\circ} \mathrm{C}$ and protein content $(\mathrm{N} \times 6.25)$ was determined by the combustion method (Leco ${ }^{\circledR}$ model, FP-528, St. Joseph, Ml) in the Nutritional Laboratory, Department of Animal, Wild and Grassland Sciences, University of the Free State.

\section{Statistical data analysis}

Agrobase Generation II software (Agrobase 2005) was used for analysis of variance. Bivariate Pearson's correlation coefficient test was applied to assess the significance of degree of association in protein content and concentrations among mineral elements (Hintze 2004). Standardisation of data was carried out as described by Ruiz et al. (1997). Principal component analysis (PCA) was used to visualise the pattern of variation of the data (NCSS 2004).

\section{Results}

\section{Mineral and protein contents}

The concentration of mineral elements and protein content of sorghum genotypes on dry weight basis are shown in Tables 1 and 2. The mean squares for the genotypes were highly significant $(\mathrm{P} \leq 0.01)$ for the concentration of all mineral elements and total protein content for the 2009 and 2010 cropping seasons (Table 1) as well as for combined analysis of variance over the two seasons (Table 2).

Genotypes Macia-SA (279.85 $\mathrm{mg} \mathrm{kg}^{-1}$ ) and 97MW6127 (218.70 $\mathrm{mg} \mathrm{kg}^{-1}$ ) were significantly higher in Ca content compared to all other genotypes (Table 2). Among genotypes, the highest concentration of Fe was recorded in genotype 216737 (37.65 mg kg$\left.{ }^{-1}\right)$; while the lowest was $22.59 \mathrm{mg} \mathrm{kg}^{-1}$ and found in genotype M141. Similarly, substantial differences in K concentration was also observed ranging from 1492.33 to $2575.00 \mathrm{mg} \mathrm{kg}^{-1}$ with the highest being in genotype M141 and lowest in genotype NO253 compared to other genotypes over the two cropping seasons (Table 2). Mn content varied from 11.28$18.54\left(\mathrm{mg} \mathrm{kg}^{-1}\right)$. It was highest in genotype M81 and lowest in genotype Birmash.

The Na concentration varied from 14.13 to $39.53 \mathrm{mg} \mathrm{kg}^{-1}$ (Table 2). The highest concentration was found in 216737 and 97MW6129 compared to other genotypes. The concentration of $\mathrm{P}$ varied from $2505.83 \mathrm{mg} \mathrm{kg}^{-1}$ in genotype $97 \mathrm{MW} 6113$ to $3453 \mathrm{mg} \mathrm{kg}^{-1}$ in genotypes Macia-SA and 97MW6127 (Table 2). The concentration of Zn over the two cropping seasons (Table 2) ranged from 20.00 to $33.42\left(\mathrm{mg} \mathrm{kg}^{-1}\right)$ and the content of genotypes 216737 and Gambella-1107 was significantly higher than all other genotypes. The $\mathrm{Zn}$ content of genotype NO253 (20.00 mg kg-1) was significantly lower than that of the other genotypes studied, while genotypes Birmash, IS9302, Baji, PI308453 and Macia-SA had identical $\mathrm{Zn}$ contents $\left(26.00 \mathrm{mg} \mathrm{kg}^{-1}\right)$. Among all genotypes, the highest concentration of $\mathrm{Mg}$ was recorded in the genotype Gambella-1107 (1390.33 $\mathrm{mg} \mathrm{kg}^{-1}$ ); and the lowest in 97MW6127 (977.50 $\left.\mathrm{mg} \mathrm{kg}^{-1}\right)$. Protein content varied from 7.20 to $11.00 \%$ 


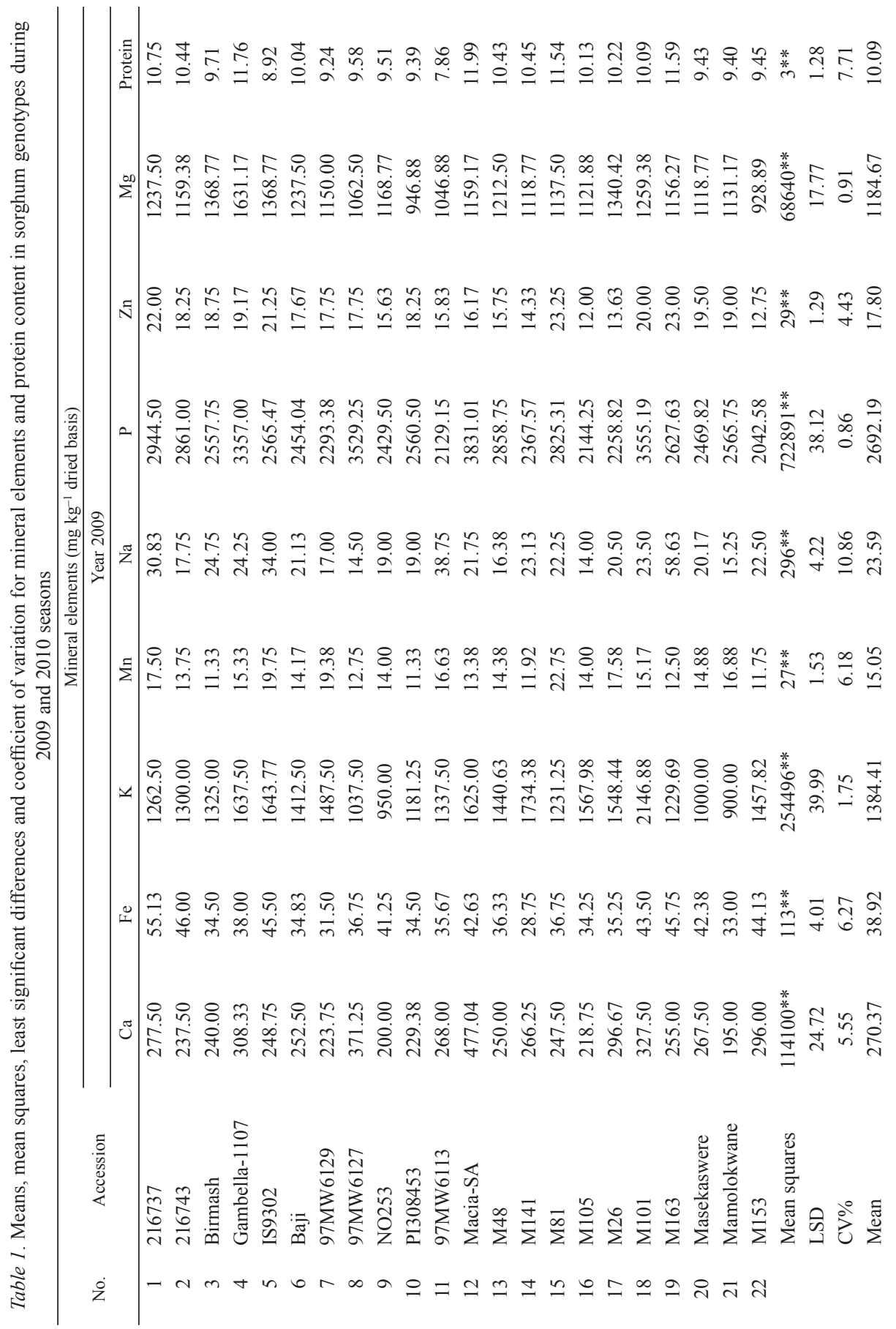




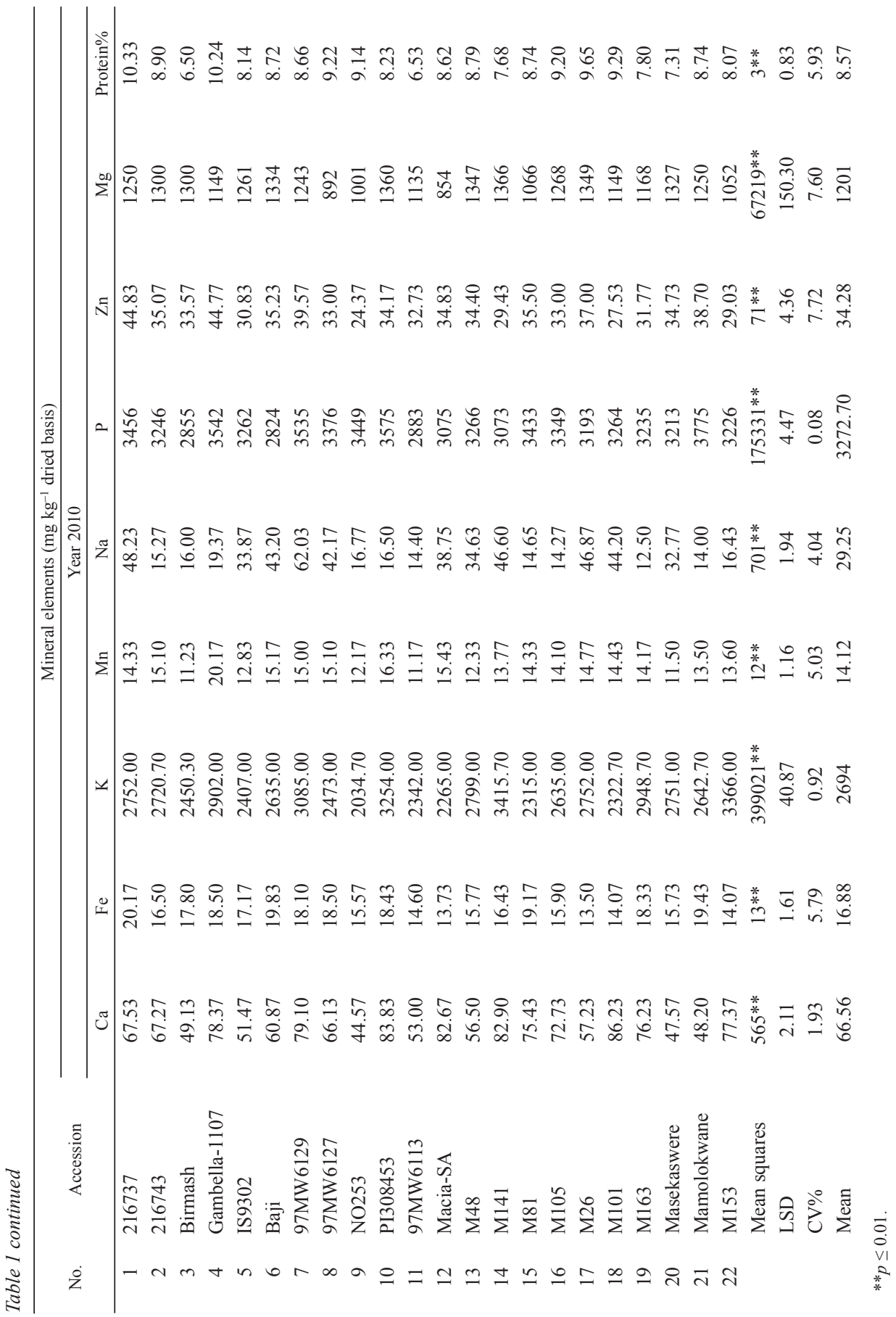




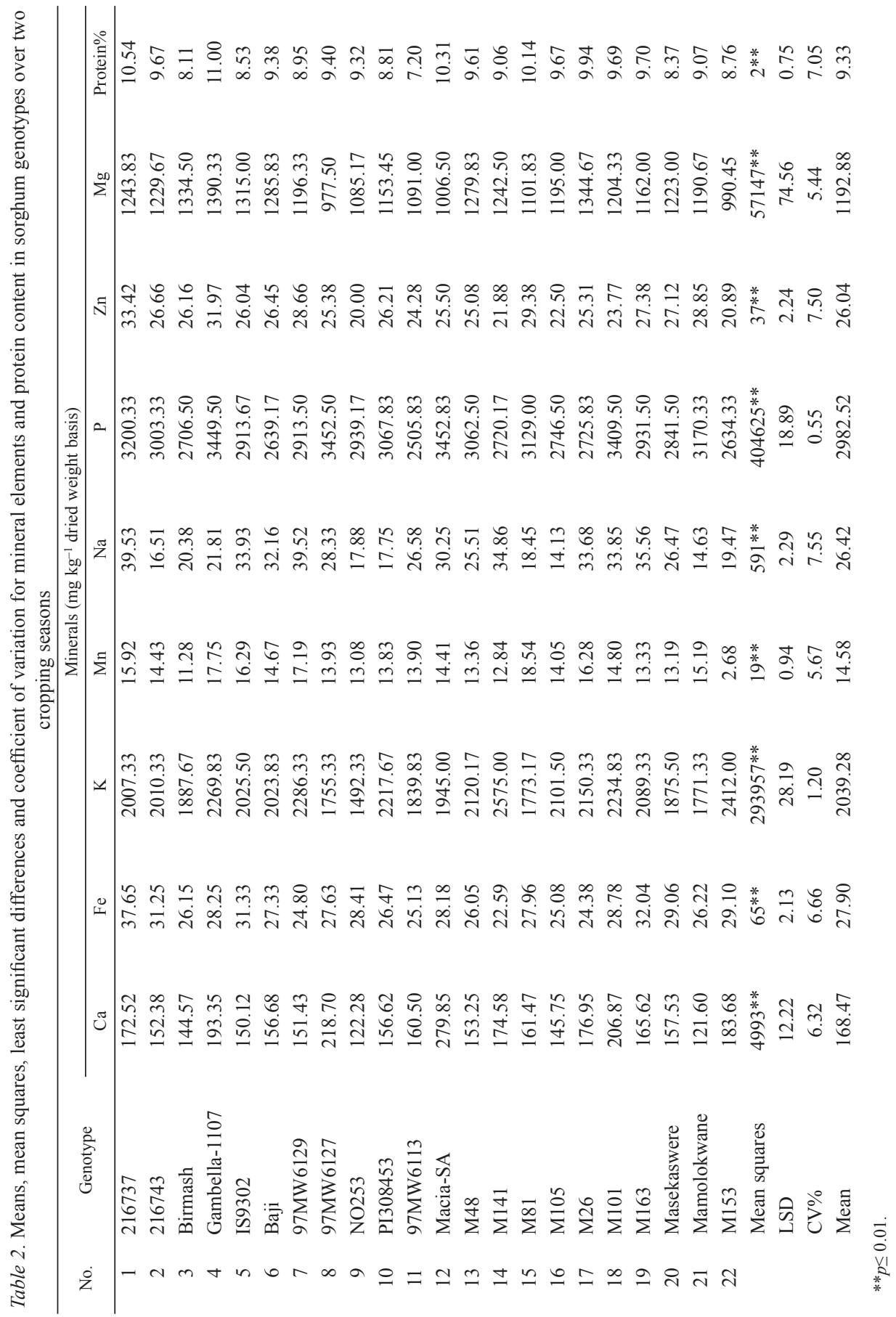



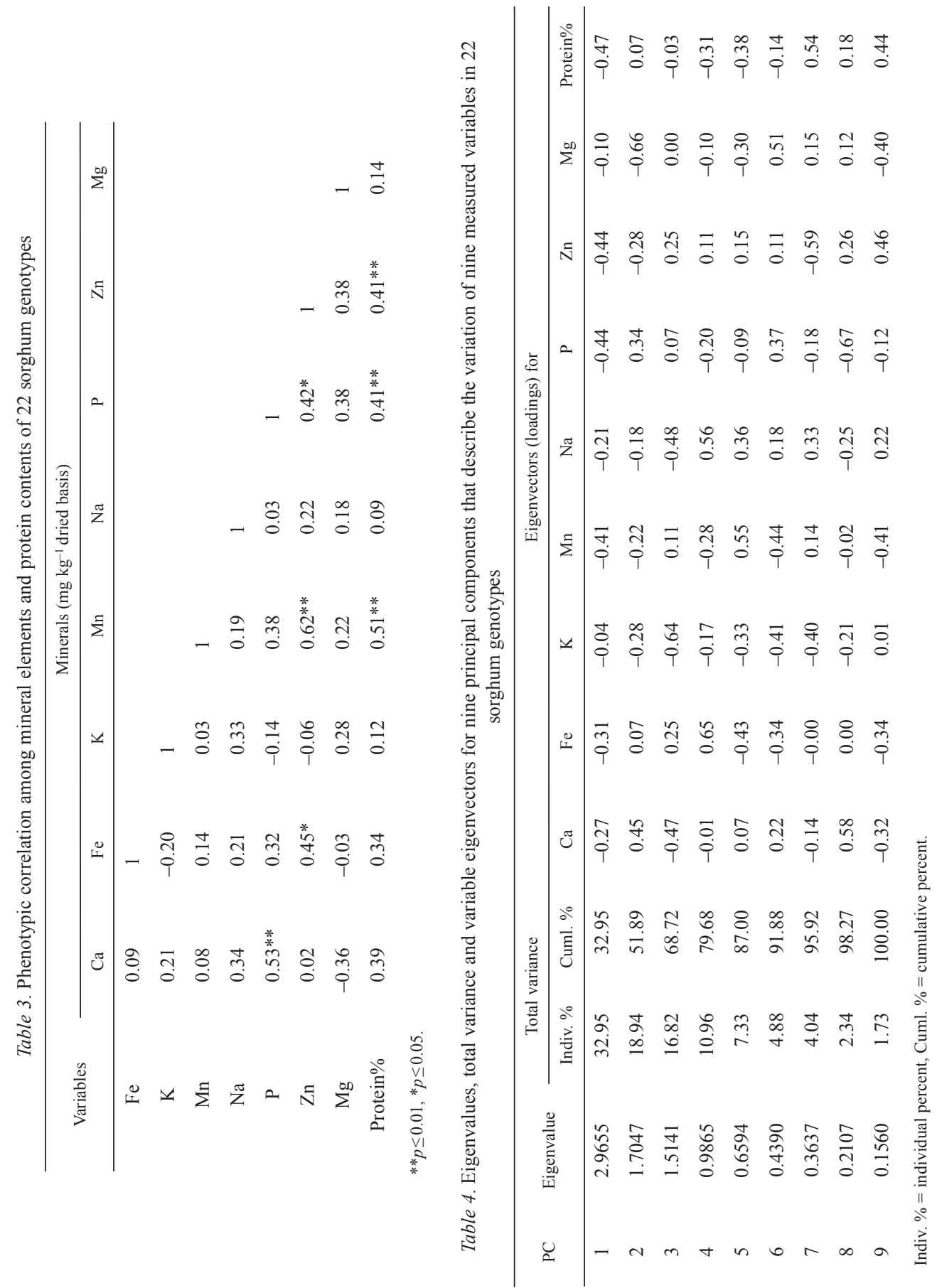
(Table 2). The highest protein content was recorded in genotype Gambella-1107 (11.00\%); while the lowest was in 97MW6113 (7.20\%) combined over two years as shown in Table 2.

Significant correlations were observed between $\mathrm{Ca}$ and $\mathrm{P}$ and $\mathrm{Mn}$ with $\mathrm{Zn}$ and protein (Table 3). Ca was highly significantly positively correlated with P. Significant positive correlations between $\mathrm{Zn}$ and Fe, Mn, and $\mathrm{P}$ were observed. There was also highly significantly positive correlation between protein and $\mathrm{Mn}, \mathrm{P}$ and $\mathrm{Zn}$.

\section{Principal component analysis}

Principal component analysis (PCA) grouped the nine traits into nine components which accounted for the entire (100\%) variability but there were only three principal components which had eigenvalues greater than one and cumulatively accounted for $68.72 \%$ of the total variation among the genotype (Table 4).

\section{Discussion}

Deficiency of mineral nutrients and protein content is a large problem in growing human populations. The mineral elements play an important role in the development of the human body (Ng'uni et al. 2012). The existence of genetic variation among genotypes for nutritional composition will help the improvement of crops for high nutritional quality through breeding in the available gene pool (Ng'uni et al. 2012; Shegro et al. 2012). Quantification of sorghum genotypes on the basis of mineral composition and protein content will help in the identification of the best parents for breeding nutritionally enhanced sorghum. In the present study, the highest Ca content was obtained in genotypes Macia-SA (279.85 $\mathrm{mg} \mathrm{kg}^{-1}$ ) and 97MW6127 (218.70 $\mathrm{mg} \mathrm{kg}^{-1}$ ), respectively (Table 2). The mineral element, Ca plays a major role in the growth and development of plant meristems, root hairs and root tips (Stanley 1995) as well as for bone development and strength (Samia et al. 2005; Shegro et al. 2012). Ca deficiency in plants leads to stunted growth and development of roots (Stanley 1995; Jimoh and Abdullahi 2011). The values recorded in the present study were higher than the values reported previously by Mohammed et al. (2010) in sorghum flour.

The Fe concentration was much higher in the first cropping season (Table 1). A reason for this could be that the rainfall and the yield were much higher in the second season, which diluted the concentration of some minerals, such as Fe, $\mathrm{Ca}$ and $\mathrm{Zn}$. This is due to the amount of rainfall variation in the growing seasons $(403 \mathrm{~mm}$ in 2009 and $867.66 \mathrm{~mm}$ in 2010 cropping seasons). The concentration of Fe varied from $22.59 \mathrm{mg} \mathrm{kg}^{-1}$ to 37.65 $\mathrm{mg} \mathrm{kg}^{-1}$ (Table 2). The values for mineral elements in this study were lower than the findings of others (Miller and Boswell 1976; Léder 2004; Waters and Pedersen 2009; Mohammed et al. 2010) but were higher than the values reported by Asha et al. (2005). The present study indicated that genotypes Gambella-1107, 97MW6127, NO253, Macia-SA and M81 revealed relatively similar Fe concentration. This indicated that they had some common characters in the uptake, translocation and the biological processes of this min- 
eral element. Fe is an essential mineral element in the biochemical system. Genotypes with high concentration of Fe could be selected as potential genotypes for biofortification through breeding to alleviate malnutrition due to lack of Fe to meet the micronutrient requirements in their diet for health, growth and development. Furthermore, the genotypes with high concentration of Fe can be formulated for baby foods for growth and repair (Okareh et al. 2015).

It was reported that $\mathrm{K}$ is the major cation of intracellular fluid which helps to regulate the acid base balance, osmotic pressure and water balance (Yellen, 2002; Olatunji and Temitope 2013). In the current study, significant genetic differences in the uptake of K was observed among the genotypes and the highest concentration was recorded in genotype M141 (Table 2). The values obtained were higher than those reported earlier (Léder 2004; Asha et al. 2005; Ragaee et al. 2006; Waters and Pedersen 2009).

There was a significant genetic variation among the genotypes in the concentration of $\mathrm{Mn}$ (Table 2). The values recorded for this mineral element ranged from $11.28 \mathrm{mg} \mathrm{kg}^{-1}$ to $18.54 \mathrm{mg} \mathrm{kg}^{-1}$. These values are lower than those reported previously (Waters and Pedersen 2009) but higher than those reported by Léder (2004).

The Na concentration varied from $14.13 \mathrm{mg} \mathrm{kg}^{-1}$ to $39.53 \mathrm{mg} \mathrm{kg}^{-1}$ in sorghum grain with the highest concentration found in 216737 and 97MW6129 (Table 2). These values were higher than values reported by (Léder 2004) but lower than those reported by Badi (2004) and Awadelkareem et al. (2009). Ca and P are very important in the formation of strong bones and teeth, for growth, blood clotting, heart function and cell metabolism (Rolfes et al. 2009; Jimoh and Abdullahi 2011). P is an essential mineral element in human nutrition and plays an important role in the structure and function of the human body. The concentration of $\mathrm{P}$ varied from $2505.83 \mathrm{mg} \mathrm{kg}^{-1}$ to $3453 \mathrm{mg} \mathrm{kg}^{-1}$ (Table 2). The highest $\mathrm{P}$ content was recorded in genotype 97MW6113 followed by genotypes Macia-SA and 97MW6127. The values obtained were higher than what was reported previously (Mohammed et al. 2010). $\mathrm{Zn}$ is a microelement which is required for body weight gain and height (Brown and Wnehler, 2002; Olatunji and Temitope 2013). It is also an essential component of proteinases and peptidases enzymes (Prince et al. 1972). Zn concentration showed a mean value of $26.04 \mathrm{mg} \mathrm{kg}^{-1}$ and ranged from $20.00 \mathrm{mg} \mathrm{kg}^{-1}$ to $33.42 \mathrm{mg} \mathrm{kg}^{-1}$ (Table 2). These values were lower than those reported by others (Waters and Pedersen 2009; Mohammed et al. 2010) but higher than those previously reported (Miller and Boswell 1976; Léder 2004). The highest Mg content was obtained in genotype Gambella-1107 (1390.33 $\mathrm{mg} \mathrm{kg}^{-1}$ ) followed by the genotype M26 with a concentration of 1344.67 $\mathrm{mg} \mathrm{kg}^{-1}$ (Table 2). The values obtained in this study were higher than those reported by others (Miller and Boswell 1976; Mohammed et al. 2010).

Protein is an essential component of the diet of animals and human and supplies the required amino acids (Okareh et al. 2015). The protein content between genotypes was significantly different with the highest amount recorded in genotype Gambella-1107 $(11.00 \%)$; while the lowest was found in 97MW6113 (7.20\%) combined over two cropping seasons (Table 2). It was in the range reported by Subramanian and Jambunathan (1984) but lower than the values previously reported (Ragaee et al. 2006; Waters and Pedersen 2009; Mohammed et al. 2010; Mokrane et al. 2010). Grain protein content in 
sorghum grains was reported to range from $6.80 \%$ to $19.60 \%$ (Subramanian et al. 1990); $5.44 \%$ to $12.90 \%$, and 10.00 to $14.00 \%$ (Neucere and Sumrell 1980; Awadelkareem 2002; Awadelkareem et al. 2009). The genotypes as well as the environment influence the protein content (Benzian et al. 1983; Ebadi 2005) during the growing seasons. This trait is significantly affected by environmental factors that affect grain filling. This could explain the big difference in mean protein values for the 2009 (10.09\%) and 2010 (8.57\%) cropping seasons (Table 1).

The genotype, growing season and soil factors as well as the relationship of these factors largely influenced the variation in mineral composition and protein content of sorghum genotypes. Of the mineral elements studied, $\mathrm{P}, \mathrm{K}, \mathrm{Mg}$ and $\mathrm{Ca}$ were the most abundant while $\mathrm{Fe}, \mathrm{Na}, \mathrm{Mn}$ and $\mathrm{Zn}$ were found in small quantities. The highest concentrations of minerals present in sorghum grain were previously reported to be $\mathrm{K}, \mathrm{P}, \mathrm{Ca}$ and $\mathrm{Mg}$ (Khalil et al. 1984). Fe values were lower than that reported by others (Léder 2004) but values for $\mathrm{Ca}, \mathrm{K}, \mathrm{Na}, \mathrm{Mn}, \mathrm{Zn}$ and $\mathrm{Mg}$ were higher in the present study. It was also reported that both the environment and effects of the genotype have an influence on micronutrient content of many crops (Zhang et al. 2010). Genotype differences, mineral concentration in the soil as well as translocation rates of the elements by the sorghum plants from the soil, as well as environmental factors such as weather conditions during the growth and development period of the plants influence the final grain composition (Shegro et al. 2012).

Breeding for high concentration of mineral elements and protein content in sorghum can be done by selecting appropriate genotypes for crossing. From the results of this study, the following genotypes could be selected and incorporated into the sorghum improvement programme in two regions of Africa (Ethiopia and South Africa): Macia-SA (Ca and P), 216737 (Fe, Na and Zn), M141 (K), genotype M81 (Mn), 97MW6129 (Na), 97MW6127 (P) and Gambella-1107 (Zn, Mg and protein). On average, Ca and K content was significantly higher in South African material and Mn was significantly higher in Ethiopian material which shows that there was a translocation difference of these minerals for the two sets of material. The content of the other minerals were very similar. The protein content of the two sets of material differed with only $0.3 \%$. This is probably due to a lack of selection for protein in both breeding programmes, but the fact that some genotypes had protein content of more than $10 \%$ indicates that there is selection potential.

The highest correlations were between $\mathrm{Ca}$ with $\mathrm{P}$; $\mathrm{Mn}$ with $\mathrm{Zn}$ and protein (Table 3). Ca was highly significantly positively correlated with P. Significant positive correlations between $\mathrm{Zn}$ and $\mathrm{Fe}, \mathrm{Mn}$, and $\mathrm{P}$ were observed. There was also highly significantly positive correlation between protein and $\mathrm{Mn}, \mathrm{P}$ and $\mathrm{Zn}$ indicating that some interactions existed between them. Therefore, breeding for high total protein content in such a manner increases the concentration of Mn, P and $\mathrm{Zn}$ and vice-versa. Waters and Pedersen (2009) also reported positive correlation between sorghum grain protein and $\mathrm{Zn}$ and $\mathrm{P}$.

PCA is a technique used to emphasize variation among the genotypes and to identify patterns in the dataset used for the analysis. It is used to make data easy to explore and visualize in a biplot. The first principal component which alone explained $32.95 \%$ of the total variability among the genotypes was mainly due to variations in $\mathrm{Fe}, \mathrm{Mn}, \mathrm{P}, \mathrm{Zn}$ and 


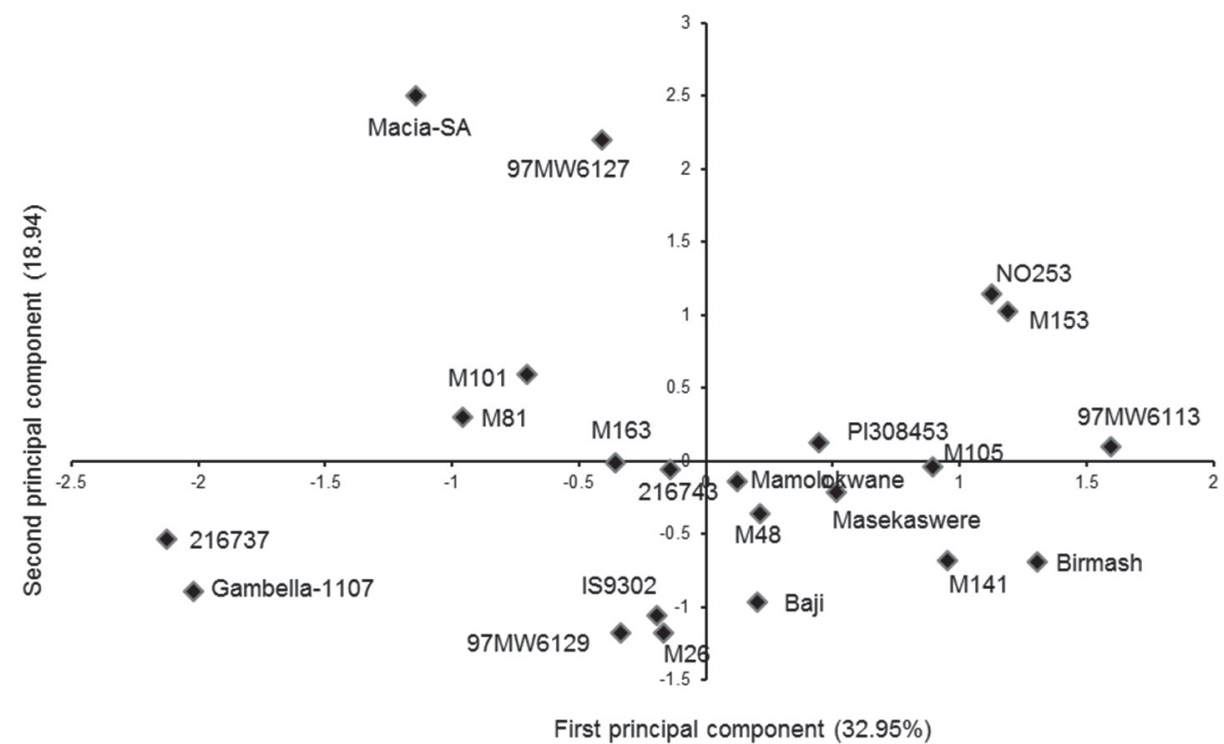

Figure 1. Configuration of the sorghum genotypes under principal component axis 1 and 2

protein with high negative loading (Table 4). The second principal component which accounted for $18.94 \%$ of the total variation was predominantly a function of $\mathrm{Ca}, \mathrm{P}$ and $\mathrm{Mg}$ with positive and negative loading, respectively. Genotypes with high PCA2 scores, therefore, would have high $\mathrm{Ca}, \mathrm{P}$ and $\mathrm{Mg}$ values. The third principal component with $16.82 \%$ variance separated the genotypes on $\mathrm{Ca}, \mathrm{K}$ and $\mathrm{Na}$, all with negative loadings. The PC1 and PC2 explained most of the variation among the genotypes, depicting a high degree of association among the protein and mineral elements. The eigenvectors of the PC1 revealed large negative loadings for all variables and a few positive loading for the variables in PC2. Chatfield and Collin (1980) and Hair et al. (1998) suggested that eigenvalues greater than one are considered significant and component loadings greater than \pm 0.30 were considered to be meaningful. Consequently, only the first three principal component axes were retained in this study and traits with loading greater than \pm 0.30 were viewed to represent the corresponding principal component axis (Hair et al. 1998). The proportion of the total variance explained by each principal component is additive, with each new component contributing less than the preceding one to the explained variance. The sign of the loading indicated the direction of the relationship between the components and the variables (Johnson 1998). A plot of the first principal component axis (PCA 1) against the second principal component axis (PCA 2) (Fig. 1) revealed that Macia-SA, 97MW6127, NO253, M153, 216737 and Gambella-1107 were most distant from the major group which was concentrated around zero. Genotypes M163, 216743, M105, Mamolokwane, 97MW6113 and PI308453 were the most stable in terms of mineral and protein contents (Fig. 1). 
There was considerable genetic variation among the genotypes for mineral and protein content. It is conceivable that these differences are genetic and may have value as biochemical markers in sorghum breeding. Genotypes with high concentration of the most important mineral elements and protein content are potential genetic sources for the future development of improved lines. Furthermore, it is important to consider these genotypes with higher contents of mineral elements for the animal feed industry. With the exception of $\mathrm{Ca}, \mathrm{K}$ and $\mathrm{Mn}$, the mineral and protein contents of the material from Ethiopia and South Africa were similar. PCA elucidated three principal component axes that explained most of the variability among the genotypes.

\section{References}

Agrobase 2005. Generation II. Agronomix Software Inc. 71 Waterloo, St.Winnipeg, Manitoba R3NOS4, Canada.

Anglani, C. 1998. Sorghum for human food: A review. Plant Foods and Hum. Nutr. 52:85-89.

Asha, V.B., Geetha, K., Sheela, K., Dhanapa, G.N. 2005. Nutritional composition of sorghum and moth bean incorporated traditional recipes. J. Hum. Ecol. 17:201-203.

Awadelkareem, A.M.A. 2002. Characterization and utilization of sorghum and millet wet-melting proteins in bread system. MSc. Thesis. University of Khartoum. Khartoum, Sudan.

Awadelkareem, A.M., Muralikrishn, G., El Tinay, A.H., Mustafa, A.I. 2009. Characterization of tannin and study of in vitro protein digestibility and mineral profile of Sudan and Indian sorghum cultivars. Pakistan J. Nutr. 8:469-476.

Badi, W.H.I. 2004. Effect of processing on antinutritional factors and mineral bioavailability of sorghum. PhD Thesis. University of Khartoum. Khartoum, Sudan.

Benzian, B., Darby, R.J., Lane, P., Widdowson, F.V., Verstreten, L.M.J. 1983. Relationship between N concentration of grain and grain yield in recent winter-wheat experiments in England and Belgium, some with large yields. J. Sci. Food Agric. 34:685-695.

BSTID-NRC (Board on Science and Technology for International Development National Research Council). 1996. Lost Crops of Africa. Academic Press. Washington, D.C., USA.

Brown, K.H., Wnehler, S.E. 2002. Zinc and Human Health. Results of Recent Trial and Implications for Programme Interventions and Research. Micronutrient initiative. Ottawa Canada International Research Centre. Ottawa, Canada.

Chatfield, C., Collin, A.J. 1980. Introduction to Multivariate Analysis. Chapman and Hall in association with Methuen, Inc. New York, NY, USA.

Dicko, M.H., Gruppen, H., Traore, A.S., Alphons, G.J., Voragen, A.G.J., van Berkel, W.J.H. 2006. Sorghum grain as human food in Africa: Relevance of content of starch and amylase activities. Afr. J. Biotechnol. 5:384-395.

Ebadi, M.R., Pourreza, J., Jamalian, J., Edris, M.A., Samie, A.H., Mirhadi, S.A. 2005. Amino acid content and availability in low medium and high tannin sorghum grain for poultry. Int. J. Poult. Sci 1:27-31.

Glew, R.H., Vanderjagt, D.J., Lockett, C., Grivetti, L.E., Smith, G.C., Pastuszyn, A., Millson, M. 1997. Amino acid, fatty acid, and mineral composition of 24 indigenous plants of Burkina Faso. J. Food Comp. Anal. 10:205-217.

Gorz, H.J., Haskins, F.A., Pedersen, J.F., Ross, W.M. 1987. Combining ability effects for mineral elements in forage sorghum hybrids. Crop Sci. 27:216-219.

Hair, J.F., Andrson, J.R., Tatham, R.E., Black, W.C. 1998. Multivariate data analysis, $5^{\text {th }}$ ed. Prentice-Hall International, Inc. London, UK.

Hintze, J.L. 2004. NCSS (Number Cruncher Statistical Systems). Kaysville, Utah, Canada. 
Idris, W.H., Abdel Rahaman, S.M., Elmaki, H.B., Babiker, E.E., EI Tinay, A.H. 2007. Effect of malt treatment on HCL extractability of calcium, phosphorus and iron of sorghum (Sorghum bicolour) cultivars. Int. J. Food Sci. Technol. 42:194-199.

Jimoh, W.L.O., Abdullahi, M.S. 2011. Analysis of some mineral elements in selected sorghum cultivars. Bayero J. Pure Appl. Sci. 4:56-58.

Johnson, D.E. 1998. Applied Multivariate Method for Data Analysis. Duxbury Press. Pacific Grove, California, USA.

Khalil, J.K., Sawaya, W.N., Al Mohammed, H.M. 1984. Chemical composition and nutritional quality of sorghum flour and bread. Qual. Plant Foods Hum. Nutr. 34:141-150.

Klopfenstein, C.F., Hoseney, R.C. 1995. Nutritional properties of sorghum and the millets. In: Dendy, D.A.V. (ed.), Am. Assoc. Cereal Chem. St Paul, MN, USA. pp. 125-168.

Lasztity, R. 1996. The Chemistry of Cereal Proteins. CRC Press, Inc. Boca Raton, FL, USA.

Léder, I. 2004. Sorghum and millets. In: Fuleky, G. (ed.), Cultivated Plants, Primarily as Food Sources. Encyclopedia of Life Support Systems, Developed under the Auspices of the UNESCO. EOLSS Publisher. Oxford, UK (http://www.eolss.net).

Miller, J., Boswell, F.C. 1976. Mineral composition of liver and kidney of rats fed corn, sorghum, and soybean grain grown with sewage sludges and NPK fertilizers. J. Agric. Food Chem. 24:935-938.

Mohammed, N.A., Mohamed Ahmed, I.A., Babiker, E.E. 2010. Nutritional evaluation of sorghum flour (Sorghum bicolor L. Moench) during processing of injera. Int. J. Biol. Life Sci. 6:1.

Mokrane, H., Amoura, H., Belhaneche-Bensemra, N., Courtin, C.M., Delcour, J.A., Nadjemi, B. 2010. Assessment of Algerian sorghum protein quality using amino acid analysis and in vitro pepsin digestibility. Food Chem. 121:719-723.

Morgounov, A., Gomez-Becerra, H.F., Abugalieva, A., Dzhunusova, M., Yessimbekova, M., Muminjanov, H., Zelenskiy, Y., Ozturk, L., Cakmak, I. 2007. Iron and zinc grain density in common wheat grown in Central Asia. Euphytica 155:193-203.

Murty, D.S., Kumar, K.A. 1995. Traditional uses of sorghum and millets. In: Dendy, D.A.V. (ed.), Sorghum and millets: Chemistry and technology, Am. Assoc. Cereal Chem. St Paul, MN, USA. pp. 185-221.

Neucere, N.J., Sumrell, G. 1980. Chemical composition of different varieties of grain sorghum. J. Agric. Chem. 28:19-21.

Ng’uni, D., Geleta, M., Hofvander, P., Fatih, M., Bryngelsson, T. 2012. Comparative genetic diversity and nutritional quality variation among some important Southern African sorghum accessions [Sorghum bicolor (L.) Moench]. AJCS 6:56-64.

Okareh, O.T., Adeolu, A.T., Adepoju, O.T. 2015. Proximate and mineral composition of plantain (Musa Paradisiaca) wastes flour; a potential nutrients source in the formulation of animal feeds. Afr. J. Food Sci. Technol. 6:53-57.

Olatunji, E.M.A., Temitope, B.M. 2013. Comparative study of mineral elements distribution in sorghum and millet from Minna and Bida, North Central Nigeria. Int. J. Food Nutr. Saf. 3:33-55.

Prince, C.A., Clark, H.E., Funkhouse, E.A. 1972. Functions of Micronutrients in Plants: Micronutrients in Agriculture. Soil Science Soc. America. Madison, Wisconsin, USA.

Ragaee, S., Abdel-Aal, E.M., Noaman, M. 2006. Antioxidant activity and nutrient composition of selected cereals for food use. Food Chem. 98:32-38.

Rolfes, S.R., Pinna, K., Whitney, E. 2009. Understanding Normal and Clinical Nutrition. Ninth ed. Wadsworth Cengage Learning. Belmont, CA, USA. p. 37.

Ruiz, M., Varela, F., Carillo, J.M. 1997. Analysis of the discriminating power of agro-morphological and biochemical descriptors in a sample of Spanish collection barely (Hordeum vulgare L.). Genet. Resour. Crop Ev. 44:247-255.

Samia, M.A., Hagir, B.E., Wisal, I.H., Elfadil, E.B., Abdullahi, H.E. 2005. Proximate composition, antinutritional factors and mineral content and availability of selected legumes and cereals grown in Sudan. J. Food Technol. 3:511-515.

Shegro, A., Shargie, N.G., Van Biljon, A., Labuschagne, M.T. 2012. Diversity in starch, protein and mineral composition of sorghum landrace accessions from Ethiopia. J. Crop Sci. Biotech. 15:275-280.

Stanley, A.B. 1995. Soil Nutrient Bioavailability. Purdue University. New York, USA. pp. 180-372. 
Subramanian, V., Jambunathan, R. 1984. Chemical composition and food quality of sorghum. In: Salunke, D.K., Chavan, J.K., Jadhav, S.J. (eds), Nutritional and processing quality of sorghum. IBA Publications. New Delhi, India.

Subramanian, V., Seetharama, N., Jambunathan, R., Venkateswara Rao, P. 1990. Evaluation of protein quality of sorghum [Sorghum bicolor (L.) Moench]. J. Agric. Food Chem. 38:1344-1347.

Waters, B.M., Pedersen, J.F. 2009. Sorghum germplasm profiling to assist breeding and gene identification for bio fortification of grain mineral and protein concentration. Proc. Int. Plant Nutrition Colloquium XVI. Dept. of Plant Sciences, UC Davis, University of California, Davis, California, USA. Available at http:// escholarship.org/uc/item/38w380dn. pp. 1-7.

Yellen, G. 2002. The voltage gatted potassium channels and their relatives. Nature 419:35-42.

Zhang, Y., Song, Q., Yan, J., Tang, J., Zhao, R., Zhang, Y., He, Z., Zou, C., Ortiz-Monasterio, I. 2010. Mineral element concentrations in grains of Chinese wheat cultivars. Euphytica 174:303-313. 